\title{
Extracellular Polysaccharide Biosynthesis by Pseudomonas NCIB 11264. Studies on Precursor-forming Enzymes and Factors Affecting Exopolysaccharide Production by Washed Suspensions
}

\author{
By A. G. WILLIAMS* AND J. W. T. WIMPENNY \\ Department of Microbiology, University College, Cardiff CF2 1TA
}

(Received 5 February 1979; revised 9 May 1979)

\begin{abstract}
An assay was developed to measure the rate of exopolysaccharide formation by washed non-proliferating suspensions of Pseudomonas NCIB 11264 grown under a range of controlled environmental conditions. The specific activities of certain of the enzymes involved in the formation of the sugar nucleotide precursors of polysaccharide biosynthesis were also measured in steady-state populations. The level of enzyme activity did not reflect either the amount of extracellular polysaccharide produced or the rate at which glucose was incorporated into exopolysaccharide, which was dependent on medium composition, environmental factors, and the rate and stage of growth of the organism. The specific activities were not affected by either cultural conditions or the separate addition of actinomycin D and chloramphenicol, indicating a constitutive biosynthetic system.
\end{abstract}

\section{INTRODUCTION}

Norval (1969), using washed suspensions of Klebsiella aerogenes grown in several different media, was able to demonstrate similar rates of polysaccharide synthesis by preparations of both exponential and stationary phase cultures. Apart from these findings, there is relatively little comparative information available on the rate of exopolysaccharide formation by bacteria grown under a range of controlled environmental conditions. Studies on exopolysaccharide synthesis in washed suspensions of bacteria have generally been undertaken to examine the effects of nutrients on polysaccharide production (Wilkinson \& Stark, 1956; Wilkinson, 1958) or, alternatively, to follow the resynthesis of capsular material following decapsulation (Bernheimer, 1953; Juni \& Heym, 1961).

Pseudomonas NCIB 11264, initially isolated from a carbohydrate-rich industrial effluent, synthesizes an extracellular acylated heteropolysaccharide (Williams et al., 1979). The influence of various growth parameters on exopolysaccharide production has been examined using both batch and continuous culture techniques (Williams \& Wimpenny, 1977, 1978). The effects of environmental factors and medium composition on the rate of exopolysaccharide formation by washed, non-proliferating suspensions of Pseudomonas NCIB 11264 are considered in this paper. The results of preliminary induction studies are also discussed.

A preliminary report of certain aspects of this work has been presented (Williams \& Wimpenny, 1975).

\section{METHODS}

Growth and maintenance of culture. Pseudomonas NCIB 11264 was routinely cultured in $200 \mathrm{ml}$ chemically defined medium in 11 baffled Erlenmeyer flasks with gyrotary incubation $\left(120\right.$ rev. min ${ }^{-1}$ ) at $30^{\circ} \mathrm{C}$ for $48 \mathrm{~h}$

* Present address: Department of Biochemistry, The Hannah Research Institute, Ayr, Scotland KA6 5HL. 
or in a 101 capacity fermentation vessel as described previously (Williams \& Wimpenny, 1977). The techniques and equipment for the continuous (chemostat) culture experiments have also been described previously (Williams \& Wimpenny, 1978).

Determination of the rate of exopolysaccharide production in non-proliferating suspensions. The rate of exopolysaccharide production by washed suspensions was determined as follows. Eacteria were harvested by centrifugation $(35000 \mathrm{~g}, 30 \mathrm{~min})$, washed twice in $0.9 \%(\mathrm{w} / \mathrm{v}) \mathrm{NaCl}$ buffered to $\mathrm{pH} 7.5$ with $001 \mathrm{M}$ Tris/ $\mathrm{HCl}$ (designated $\mathrm{NaCl} / \mathrm{Tris}$ ) and resuspended in $0.01 \mathrm{M}-\mathrm{KH}_{2} \mathrm{PO}_{4}(\mathrm{pH} 7.0)$ to give a suspension containing approximately 1 to $2 \mathrm{mg}$ protein $\mathrm{ml}^{-1}$. All solutions and suspensions were kept at 0 to $4{ }^{\circ} \mathrm{C}$ throughout.

The assay was based on the incorporation of $\left[\mathrm{U}_{-}{ }^{14} \mathrm{C}\right] \mathrm{glucose}$ into exopolysaccharide material under nongrowing conditions. Protein synthesis inhibitors were not included because of possible non-specific interference in polysaccharide biosynthesis. The $A_{520}$ remained constant during the $30 \mathrm{~min}$ incubation period. The reaction mixture, containing nitrogen-free defined medium ( $\mathrm{pH} 7 \cdot 0)$, [U- $\left.{ }^{14} \mathrm{C}\right]$ glucose $(5 \mu \mathrm{Ci}$; The Radiochemical Centre, Amersham) and glucose $(28 \mathrm{nmol})$, was equilibrated at $30^{\circ} \mathrm{C}$ before adding cell suspension to a total volume of $5 \mathrm{ml}$. The mixture was gently shaken at $30^{\circ} \mathrm{C}$ and samples $(0.5 \mathrm{ml})$ were removed at intervals and mixed with an equal volume of chilled formalin $(2 \%, v / v)$ to stop the reaction. Bacteria were removed by centrifugation ( $5000 \mathrm{~g}$ for $15 \mathrm{~min})$ and samples $(50 \mu \mathrm{l})$ of the supernatant were applied to Whatman no. 1 paper which was irrigated for $15 \mathrm{~h}$ in ethanol/1.0 M-ammonium acetate $(7: 3, \mathrm{v} / \mathrm{v} ; \mathrm{pH} 7.5)$ to remove low molecular weight materials. The areas at the origin containing ${ }^{14} \mathrm{C}$-labelled polymeric material (Williams \& Wimpenny, 1975) were cut out, suspended in toluene $(10 \mathrm{ml})$ containing $0.5 \%(\mathrm{w} / \mathrm{v}) 2,5-$ diphenyloxazole, and their radioactivities were determined using a Beckman LS-100 ambient temperature scintillation spectrometer. The efficiency of ${ }^{14} \mathrm{C}$ counting on paper was approximately $30 \%$.

Using this assay procedure, the rate of glucose incorporation into polysaccharide $[\mu \mathrm{g} \text { (mg cell protein })^{-1}$ $\mathrm{h}^{-1}$ ] by washed non-proliferating bacterial suspensions was proportional to the protein content $(0 \cdot 1$ to $1.0 \mathrm{mg} \mathrm{ml}^{-1}$ ) and was determined for a range of controlled steady-state growth conditions, which, except

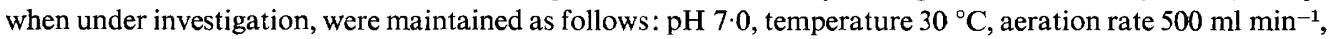
impeller speed $900 \mathrm{rev}$. $\mathrm{min}^{-1}$, glucose input $20 \mathrm{mg} \mathrm{ml}^{-1}, \mathrm{NH}_{4} \mathrm{Cl}$ input $0.5 \mathrm{mg} \mathrm{ml}^{-1}, \mathrm{KH}_{2} \mathrm{PO}_{4}$ input $5.44 \mathrm{mg} \mathrm{ml}^{-1}$.

Experiments with chloramphenicol and actinomycin $D$. (i) Effect of protein synthesis inhibitors on exopolysaccharide formation. The organism, previously shown to be sensitive to chloramphenicol and actinomycin $D$ at 100 to $250 \mu \mathrm{g} \mathrm{ml}^{-1}$ and 15 to $25 \mu \mathrm{g} \mathrm{ml}^{-1}$, respectively, was grown in continuous culture under conditions of carbon or nitrogen limitation. Bacteria were harvested aseptically, washed twice with $\mathrm{NaCl} / \mathrm{Tris}(\mathrm{pH} 7 \cdot 5)$, resuspended in $0.01 \mathrm{M}-\mathrm{KH}_{2} \mathrm{PO}_{4}(\mathrm{pH} 7.0)$ and used to inoculate batch cultures in defined media (with and without added chloramphenicol at $500 \mu \mathrm{g} \mathrm{ml}^{-1}$ ). Identical results were obtained when the bacteria were washed with the $\mathrm{KH}_{2} \mathrm{PO}_{4}$ solution prior to resuspension in the same buffer. Polysaccharide concentrations were determined gravimetrically after propan-2-ol precipitation, or viscometrically at concentrations below $500 \mu \mathrm{g} \mathrm{m}^{-1}$ (Williams \& Wimpenny, 1977).

Polysaccharide production was also assayed by the $\left[\mathrm{U}-{ }^{14} \mathrm{C}\right] \mathrm{glucose}$ incorporation procedure. The nitrogenfree reaction mixture was supplemented with chloramphenicol $\left(100 \mu \mathrm{g} \mathrm{ml}^{-1}\right)$ and the total volume, including the inoculum, was $5 \mathrm{ml}$.

(ii) Effect of inhibitors on the rate of exopolysaccharide formation. Shaken flask cultures $(500 \mathrm{ml})$ grown for $48 \mathrm{~h}$ under carbon-limiting or carbon-excess conditions ( 1 and $20 \mathrm{mg} \mathrm{ml}^{-1}$ glucose, respectively) were harvested at $4{ }^{\circ} \mathrm{C}$ by centrifugation $(35000 \mathrm{~g}, 30 \mathrm{~min})$. Eacteria were washed twice with chilled $\mathrm{NaCl} / \mathrm{Tris}$ (pH 7.5) and resuspended in $15 \mathrm{ml} 0.01 \mathrm{M}-\mathrm{KH}_{2} \mathrm{PO}_{4}(\mathrm{pH} 7.0)$. Aliquots $(5 \mathrm{ml})$ were transferred to each of three flasks containing $20 \mathrm{ml}$ defined medium supplemented with glucose $\left(40 \mathrm{mg} \mathrm{ml}^{-1}\right)$ and Casamino acids $(0.2 \%, \mathrm{w} / \mathrm{v})$. Protein synthesis inhibitors were included as follows: (1) control, no inhibitor present; (2) actinomycin $\mathrm{D}\left(15 \mu \mathrm{g} \mathrm{ml}^{-1}\right)$; (3) chloramphenicol $\left(100 \mu \mathrm{g} \mathrm{ml}^{-1}\right)$. The flasks were shaken in a water bath at $30^{\circ} \mathrm{C}$. At intervals between 0 and $5 \mathrm{~h}$, samples $(5 \mathrm{ml})$ were removed and bacteria were recovered by centrifugation. After washing twice in $\mathrm{NaCl} /$ Tris $(\mathrm{pH} 7.5)$ they were resuspended in $5 \mathrm{ml} 0.01 \mathrm{M}-\mathrm{KH}_{2} \mathrm{PO}_{4}(\mathrm{pH} 7.0)$. The rates of polysaccharide production by the two types of bacteria (carbon-limited and carbon-excess) under the three different incubation conditions were measured by the $\left[{ }^{14} \mathrm{C}\right]$ glucose incorporation technique.

Preparation of cell-free extracts and enzyme assays. Steady-state chemostat-grown bacteria from $500 \mathrm{ml}$ culture were harvested by centrifugation $(35000 \mathrm{~g}, 30 \mathrm{~min})$, washed twice with $\mathrm{NaCl} / \mathrm{Tris}(\mathrm{pH} 7.5)$ and resuspended in $10 \mathrm{ml} 0.01 \mathrm{M}-\mathrm{KH}_{2} \mathrm{PO}_{4}(\mathrm{pH} 7 \cdot 0)$. A portion $(1 \mathrm{ml})$ of the suspension was used to determine the rate of $\left[{ }^{14} \mathrm{C}\right]$ glucose incorporation into exopolysaccharide. The remainder of the washed suspension was passed twice through a French press and treated with DNAase; unbroken organisms were removed by centrifugation $(6000 \mathrm{~g}, 15 \mathrm{~min})$. The crude cell-free extract thus obtained was centrifuged $(115000 \mathrm{~g}, 60 \mathrm{~min})$ and the supernatant fraction was carefully decanted and stored at $4{ }^{\circ} \mathrm{C}$. Assays were always performed on freshly prepared samples, not on fractions that had been stored or deep frozen.

Hexokinase activity was assayed by the method reported by Norval \& Sutherland (1973) and UDPgalactose 4-epimerase by the procedure of Maxwell et al. (1962). The formation of dTDP-L-rhamnose from 
dTDP-D-glucose was assayed by the method of Glaser \& Kornfeld (1966), and GDPmannose pyrophosphorylase activity was estimated by the method of Munch-Petersen (1962). Sugar nucleotides were purchased from Sigma.

Analytical methods. The protein content of the cell-free fractions and of the washed suspensions following lysis ( $1 \mathrm{M}-\mathrm{NaOH}$ : cell preparation, $1: 1$; lysed at $100^{\circ} \mathrm{C}$ for $5 \mathrm{~min}$ ) was determined by the method of Lowry, with a bovine serum albumin standard.

\section{RESULTS}

Rate of polysaccharide production during the growth cycle

Samples were collected at various stages throughout the growth cycle of the organism $\mathrm{n}$ a chemically defined medium, and the rate of [U-14 C]glucose incorporation into exopolysaccharide by washed suspensions was determined. The incorporation rate remained low [20 to $55 \mu \mathrm{g}$ glucose incorporated (mg protein $)^{-1} \mathrm{~h}^{-1}$ ] and did not increase until the late-exponential growth phase when activity had trebled. The incorporation rate in the stationary phase [196 $\mu$ g glucose incorporated (mg protein $\left.)^{-1} \mathrm{~h}^{-1}\right]$ was approximately nine times higher than during the early-exponential phase. This incorporation pattern parallels the appearance of exopolysaccharide (Williams \& Wimpenny, 1977).

\section{Effect of growth rate and growth conditions on the rate of exopolysaccharide formation}

The organism was grown in a chemically defined medium under strictly controlled conditions in a single-stage continuous culture system and the rate of glucose incorporation by washed suspensions was determined for the wide range of steady-state growth conditions reported by Williams \& Wimpenny (1978).

(i) Growth rate. The ability of the organism to form exopolysaccharide was related to its growth rate (Table 1) and showed an apparent optimum value at $D=0.04$ to $0.06 \mathrm{~h}^{-1}$. This may have arisen as a result of limitation due to the high culture viscosity which developed at these lower dilution rates. As the dilution rate in the chemostat approached the maximum specific growth rate in batch culture the rates of glucose incorporation became very similar [ 30 and 22 to $27 \mu \mathrm{g}$ glucose incorporated (mg protein) $)^{-1} \mathrm{~h}^{-1}$, respectively].

(ii) Medium composition and growth conditions. The maximum rates of glucose incorporation into polysaccharide were measured in bacteria grown under conditions of nitrogen limitation with excess phosphate and glucose at $\mathrm{pH} 7 \cdot 0$ and $30^{\circ} \mathrm{C}$ (Table 1).

\section{Effect of protein synthesis inhibitors on exopolysaccharide formation}

Washed bacteria grown in a chemostat under conditions of carbon or nitrogen limitation were re-inoculated into defined medium with or without chloramphenicol $\left(500 \mu \mathrm{g} \mathrm{ml}^{-1}\right)$ and grown as a batch culture. In the absence of chloramphenicol the final polysaccharide concentrations after $12 \mathrm{~h}$ were similar for both carbon- and nitrogen-limited organisms (5.6 and $5.9 \mathrm{mg} \mathrm{ml}^{-1}$, respectively) (Fig. Ia). In the presence of chloramphenicol, polysaccharide synthesis by both types was considerably impaired and could only be detected in culture supernatants by viscometry (Fig. $1 b$ ). The chemical composition of the material formed during the incubation was not determined. Although the cultures of nitrogenlimited organisms continued to produce exopolysaccharide the amount was very low (approx. $30 \mu \mathrm{g} \mathrm{ml}^{-1}$ after $12 \mathrm{~h}$ incubation) and with cultures of carbon-limited organisms none was detected. Growth of both types of culture was suppressed ( $A_{520}$ changes over the $12 \mathrm{~h}$ period were 1.25 to 1.75 and 3.0 to 3.6 , respectively) but the $\mathrm{pH}$ of the cultures was not inhibitory to polysaccharide formation.

The rate of glucose incorporation by cultures of nitrogen-limited organisms [78 $\mu \mathrm{g}(\mathrm{mg}$ protein $)^{-1} \mathrm{~h}^{-1}$ ] was reduced in the presence of chloramphenicol $\left(100 \mu \mathrm{g} \mathrm{ml}^{-1}\right)$ to $42 \mu \mathrm{g}(\mathrm{mg}$ protein $)^{-1} \mathrm{~h}^{-1}$, but was considerably higher than the rate measured in cultures of carbonlimited organisms $\left[6.8 \mu \mathrm{g}(\mathrm{mg} \text { protein })^{-1} \mathrm{~h}^{-1}\right]$ (Fig. 2). The rate of incorporation by the latter cultures was unaltered in the presence of the inhibitor. 


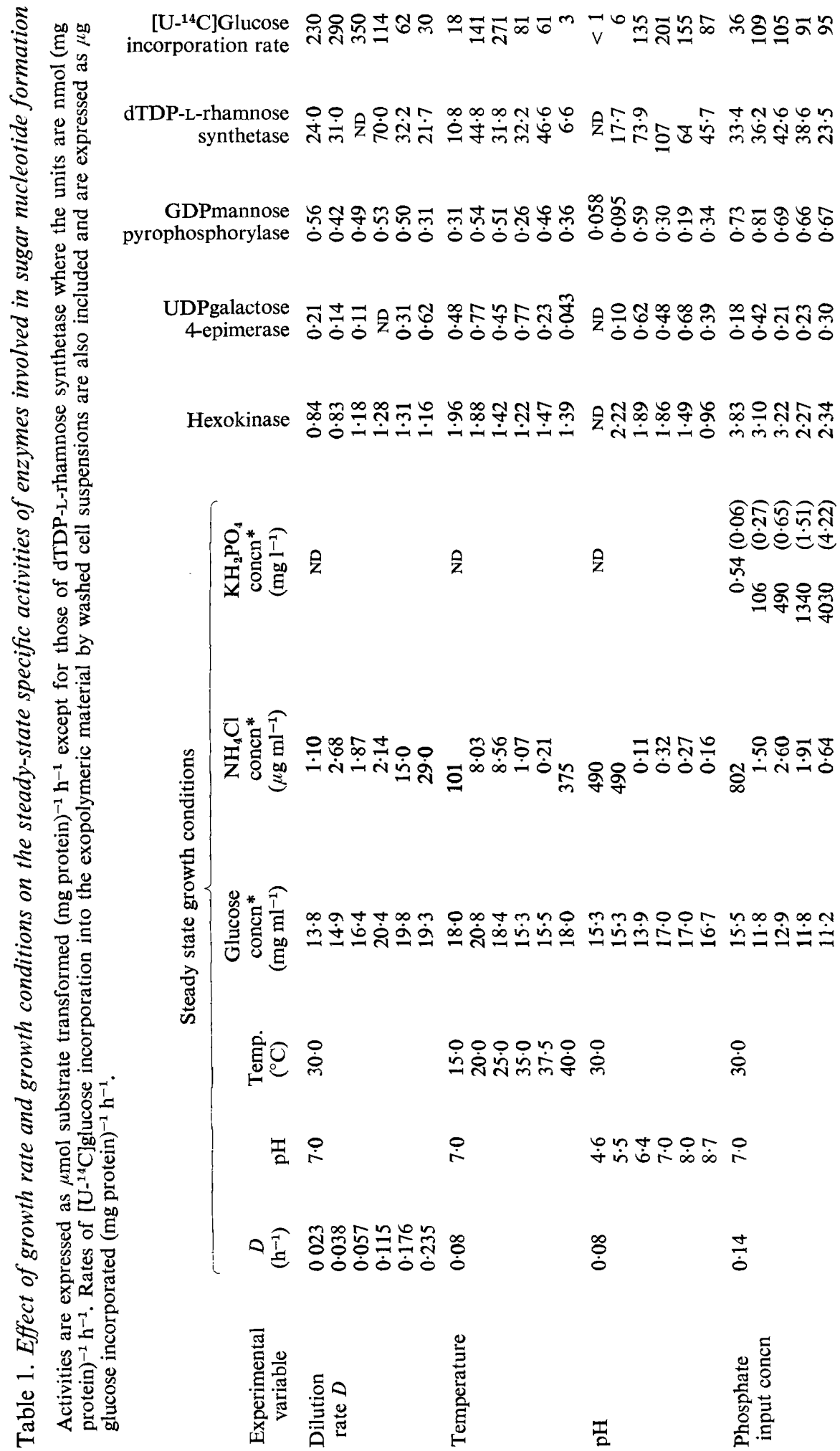




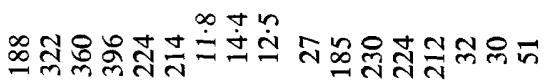

ب0ㅇ oboo lom

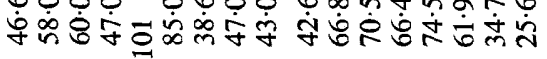

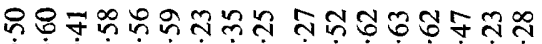

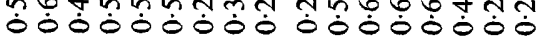

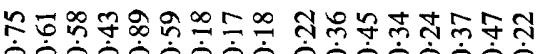

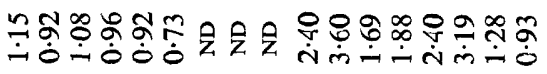

令

安

咅

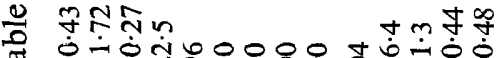

草

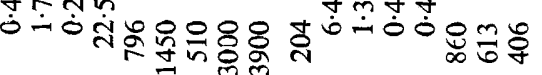

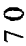

$\stackrel{9}{r}$

8

$\frac{0}{0}$

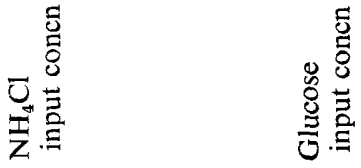



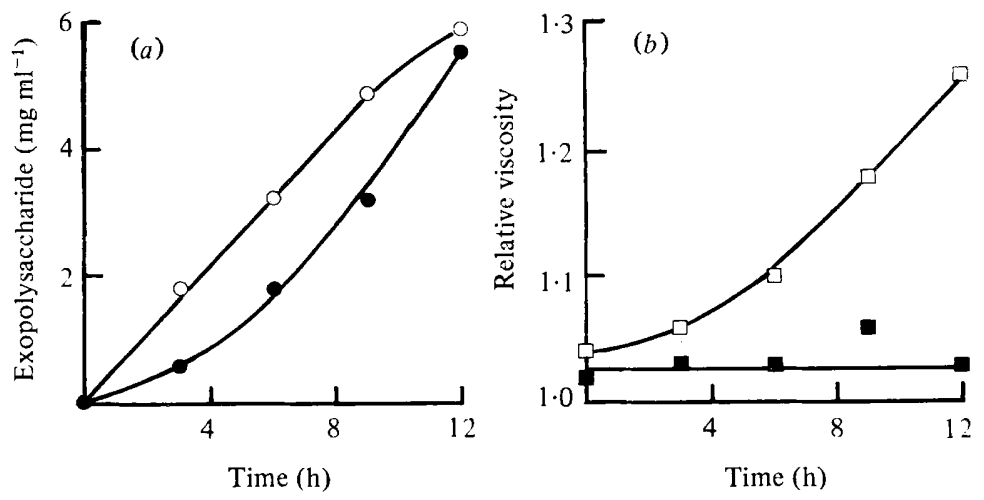

Fig. 1. Exopolysaccharide production by washed suspensions of carbon- or nitrogen-limited chemostat-grown Pseudomonas NCIB 11264 on transfer to glucose defined medium with or without chloramphenicol $\left(500 \mu \mathrm{g} \mathrm{ml}^{-1}\right)$. (a) Polysaccharide production by cultures of nitrogen-limited (O) and carbon-limited (O) organisms in the absence of chloramphenicol were estimated by precipitation with propan-2-ol. (b) Exopolymer production by cultures of nitrogen-limited ( $\square$ ) and carbon-limited ( $\boldsymbol{\square}$ ) organisms in the presence of chloramphenicol was followed viscometrically at $25 \pm 0 \cdot 2{ }^{\circ} \mathrm{C}$ using a Zimm-Crothers viscometer.

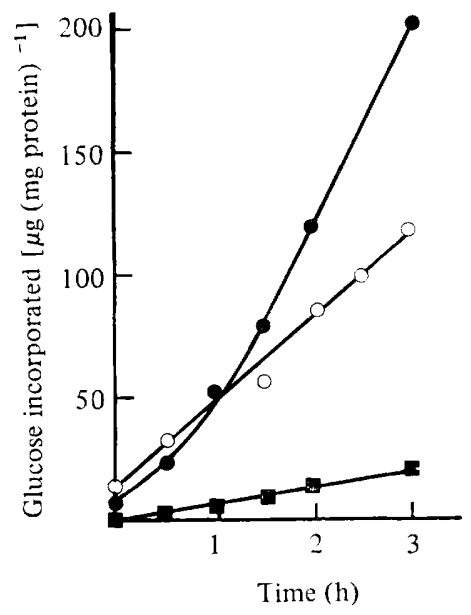

Fig. 2. Exopolysaccharide production, determined using the $\left[\mathrm{U}-{ }^{14} \mathrm{C}\right] \mathrm{glucose}$ incorporation assay, by washed suspensions of nitrogen-limited chemostat-grown Pseudomonas NCIB 11264 in the standard incubation mixture (O) and in the presence of chloramphenicol $\left(100 \mu \mathrm{g} \mathrm{ml}^{-1}\right)(\bigcirc)$. Incorporation by suspensions of carbon-limited organisms in the standard incubation mixture is also shown ( $\square$ ).

\section{Effect of protein synthesis inhibitors on the rate of exopolysaccharide formation}

The rate of polysaccharide formation by washed suspensions of carbon- or nitrogenlimited Pseudomonas NCIB 11264 was determined over a $5 \mathrm{~h}$ period following transfer to defined media containing protein synthesis inhibitors (Table 2). The rate of glucose incorporation by organisms grown under carbon-excess conditions increased fivefold throughout the incubation period. The original low incorporation rate may be attributed to the low environmental $\mathrm{pH}(5 \cdot 8)$ that had developed during the $48 \mathrm{~h}$ initial batch culture. After $5 \mathrm{~h}$ the measured rate was reduced by $10 \%$ in the presence of chloramphenicol, whereas no reduction in the rate occurred in the presence of actinomycin $D$.

Initially the activity under carbon limitation was reduced by about tenfold as compared with the rate measured in polysaccharide-producing cultures. However, at the end of the 
Table 2. Effect of the protein synthesis inhibitors chloramphenicol and actinomycin $D$ on the rates of glucose incorporation into exopolysaccharide by suspensions of nitrogen-limited and carbon-limited Pseudomonas NCIB 11264 following transfer to environmental conditions farouring exopolysaccharide formation

Rates of polysaccharide production are expressed as $\mu$ g glucose incorporated (mg protein) $)^{-1} \mathrm{~h}^{-1}$.

$\begin{array}{lcccccc}\begin{array}{c}\text { Time } \\ \text { (h) }\end{array} & \overbrace{\text { Control }}^{\text {Actinomycin D }} \\ \left(15 \mu \mathrm{g} \mathrm{ml}^{-1}\right) & \begin{array}{c}\text { Chloram- } \\ \text { phenicol } \\ \left(100 \mu \mathrm{g} \mathrm{ml}^{-1}\right)\end{array} & \overbrace{\text { Control }} & \begin{array}{c}\text { Actinomycin D } \\ \left(15 \mu \mathrm{g} \mathrm{ml}^{-1}\right)\end{array} & \begin{array}{c}\text { Chloram- } \\ \text { phenicol } \\ \left(100 \mu \mathrm{g} \mathrm{ml}^{-1}\right)\end{array} \\ 0 & 59 \cdot 5 & 74 \cdot 8 & 63 \cdot 1 & 3 \cdot 4 & 17 \cdot 9 & 5 \cdot 8 \\ 1 \cdot 5 & 160 & 212 & 195 & 162 & 178 & 149 \\ 3 \cdot 0 & 215 & 219 & 237 & 222 & 221 & 179 \\ 5 \cdot 0 & 292 & 305 & 264 & 264 & 230 & 210\end{array}$

$5 \mathrm{~h}$ period it had risen to within $10 \%$ of the latter value. The inclusion of chloramphenicol led to a $20 \%$ reduction in activity.

At the end of the incubation period polysaccharide could be recovered by propan-2-ol precipitation from the cell-free supernatants of each of the six incubation flasks. Slight growth was observed only in flasks containing organisms originally grown under carbonexcess conditions; this growth was partially inhibited by chloramphenicol or actinomycin $\mathrm{D}$.

Apparently, the inclusion of a protein synthesis inhibitor prevented neither the formation of the exopolysaccharide nor the increase in activity of the synthesizing system, indicating that the system was constitutive rather than inducible.

\section{Effect of growth conditions on steady-state enzyme levels}

The specific activities of the enzymes assayed did not exhibit the pronounced variations shown by the glucose incorporation assay and were not indicative of an inducible system. In particular the activity of hexokinase was unaffected by environmental and nutritional changes (Table 1). The specific activities of the other three enzymes were slightly reduced under conditions of carbon limitation, and at extremes of both temperature and $\mathrm{pH}$. On changing from carbon to nitrogen limitation, the rate of exopolysaccharide synthesis, as measured by glucose incorporation, was increased 8.5- to 9-fold. However, the assays showed little difference in the specific activities of these enzymes in preparations from bacteria grown under conditions which caused large changes in the rate of exopolysaccharide formation.

\section{DISCUSSION}

The rate of exopolysaccharide formation by Pseudomonas NCIB 11264 was affected not only by environmental factors such as $\mathrm{pH}$ and temperature, but also by the concentrations of essential nutrients. Maximum incorporation rates were measured with bacteria grown under conditions of nitrogen limitation and with excess carbon substrate at $\mathrm{pH} 7$ and at $30{ }^{\circ} \mathrm{C}$, as indicated in the fermentation studies (Williams \& Wimpenny, 1977, 1978). Incorporation rates were reduced under conditions of phosphate or glucose limitation. Similarly, the production of xanthan gum by Xanthomonas campestris, although not requiring active growth, was reduced at low bacterial concentrations (Moraine \& Rogovin, 1966,1973 ), and the specific product formation rate declined at higher viscosities.

Polysaccharide formation was also influenced by both the growth rate and stage of growth of the organism. Whereas the rate of polysaccharide production by Klebsiella aerogenes in liquid media was greatest during the exponential phase of growth (Duguid \& Wilkinson, 1953), and washed suspensions of both exponential and stationary phase organisms of a $K$. aerogenes slime-forming mutant formed polysaccharide at very similar rates (Norval, 
1969), Pseudomonas NCIB 11264 produced the exopolymer maximally during the lateexponential and stationary growth phases and thus resembles other strains of Pseudomonas (Haynes, 1951; Eagon, 1956) and Zoogloea (Parsons \& Dugan, 1971; Unz \& Farrah, 1976).

Although actinomycin D did not suppress either exopolysaccharide formation or the increase in activity of the synthesizing system in carbon-limited organisms on transfer to carbon-excess conditions, exopolymer formation by washed suspensions was adversely affected by chloramphenicol. Chloramphenicol is an effective inhibitor of bacterial protein synthesis and at higher concentrations will affect other cell processes (Hahn, 1967). The transfer of monosaccharides from nucleotide precursors to the lipid carrier has been shown to be inhibited by chloramphenicol (Stow et al., 1971; Sutherland et al., 1971), and exopolysaccharide production by Pseudomonas NCIB 11264 may be similarly affected by chloramphenicol.

The specific activities of the enzymes examined remained relatively constant and did not reflect either the amount of polysaccharide produced or the rate at which glucose was incorporated into exopolymeric material, although all of the enzymes assayed are involved in various metabolic processes, none being restricted solely to the synthesis of exopolysaccharide. Similarly, Norval \& Sutherland (1973) were unable to observe any correlation between the loss of exopolysaccharide formation and the activities of the enzymes forming the nucleotide precursors in a number of non-mucoid mutant strains of $K$. aerogenes. Our findings and the results of the inhibitor studies are indicative of a constitutive biosynthetic system. Pullulan elaboration by Pullularia pullulans is inducible and can be inhibited by cycloheximide (Catley, 1972).

The rate at which Pseudomonas NCIB 11264 incorporated $\left[{ }^{14} \mathrm{C}\right]$ glucose into exopolysaccharide increased markedly after the mid-exponential growth phase although activity was detectable throughout the complete growth cycle. The rate also decreased as the growth rate of the organism was increased in the continuous culture system. Many of the enzymes and precursors of exopolysaccharide biosynthesis are involved in the elaboration of other cellular polysaccharides and the decreased synthetic activity of the exopolymer system at higher growth rates may reflect competition for these enzymes and precursors in branched pathways leading to the synthesis of the more essential cellular polysaccharides. It is also possible that the organism may resemble the conditional (CR) mutants of $K$. aerogenes (Norval \& Sutherland, 1969) which are believed to contain depleted levels or activity of the glycosyl carrier.

A.G.W. acknowledges the financial support of a C.A.P.S. studentship from the S.R.C. and Tate \& Lyle Ltd. We thank Dr I. W. Sutherland for advice leading to the development of the $\left[{ }^{14} \mathrm{C}\right]$ exopolysaccharide assay.

\section{REFERENCES}

Bernheimer, A. W. (1953). Synthesis of type III pneumococcal polysaccharide by suspensions of resting cells. Journal of Experimental Medicine 97, 591-600.

CATley, B. J. (1972). Pullulan elaboration, an inducible system of Pullularia pullulans. FEBS Letters 20, 174-176.

Duguid, J.P. \& Wilkinson, J.F. (1953). The influence of cultural conditions on polysaccharide production by Aerobacter aerogenes. Journal of General Microbiology 9, 174-189.

EAGON, R. G. (1956). Studies on polysaccharide formation by Pseudomonas fluorescens. Canadian Journal of Microbiology 2, 673-676.

Glaser, L. \& Kornfeld, S. (1966). Methods in
Enzymology 8, 303-305.

HaHN, F. E. (1967). In Antibiotics, vol. 1, pp. 308312. Edited by D. Gottlieb \& P. D. Shaw. New York: Springer.

HAYNes, W. G. (1951). Pseudomonas aeruginosa: its characterization and identification. Journal of General Microbiology 5, 939-950.

Juni, E. \& Heym, G. A. (1961). Capsule resynthesis by decapsulated resting cell suspensions. Bacteriological Proceedings, 193.

Maxwell, E. S., Kurahashi, K. \& Kalckar, H. M. (1962). Methods in Enzymology 5, 174-189. Moraine, R. A. \& Rogovin, P. (1966). Kinetics of polysaccharide B-1459 fermentation. Biotechnology and Bioengineering 8, 511-524. 
Moraine, R. A. \& Rogovin, P. (1973). Kinetics of the xanthan fermentation. Biotechnology and Bioengineering 15, 225-237.

Munch-Petersen, A. (1962). Methods in Enzymology 5, 171-174.

Norval, M. (1969). Ph.D. thesis, Edinburgh University.

Norval, M. \& Sutherland, I. W. (1969). A group of Klebsiella mutants showing temperature dependent polysaccharide synthesis. Journal of General Microbiology 57, 369-377.

Norval, M. \& Sutherland, I. W. (1973). The production of enzymes involved in exopolysaccharide synthesis in Klebsiella aerogenes Types 1 and 8. European Journal of Biochemistry 35, 209-215.

Parsons, A. B. \& Dugan, P. R. (1971). Production of extracellular polysaccharide matrix by Zcogloea ramigera. Applied Microbiology 21, 657-661.

Stow, M., Starkey, B. J., Hancock, I. C. \& BADDILEY, J. (1971). Inhibition by chloramphenicol of glucose transfer in teichoic acid biosynthesis. Nature, New Biology 229, 56-57.

Sutherland, I. W., Norval, M. \& Poxton, I. R. (1971). Transfer of monosaccharides to lipid intermediates in the synthesis of Klebsiella exopolysaccharides. Journal of General Microbiology 68, v.

UnZ, R. F. \& Farrah, S. R. (1976). Exopolymer production and flocculation by Zoogloea MP6. Applied and Environmental Microbiology 31, 623626.

Wilkinson, J. F. (1958). The extracellular polysaccharides of bacteria. Bacteriological Reviews 22, 46-73.

Wilkinson, J. F. \& Stark, G. H. (1956). The synthesis of polysaccharide by washed suspensions of Klebsiella aerogenes. Proceedings of the Royal Physical Society of Edinburgh 25, 35-38.

Williams, A. G. \& WimpenNy, J. W. T. (1975). Exopolysaccharide formation in non-proliferating suspensions of Pseudomonas PB1. Transactions of the Biochemical Society 3, 983-985.

Williams, A. G. \& WimpenNy, J. W. T. (1977). Exopolysaccharide production by Pseudomonas NCIB11264 grown in batch culture. Journal of General Microbiology 102, 13-21.

Williams, A. G. \& WimpenNY, J. W. T. (1978). Exopolysaccharide production by Pseudomonas NCIB11264 grown in continuous culture. Journal of General Microbiology 104, 47-57.

WILliams, A. G., WIMPENNY, J. W. T. \& LAWSON, C. J. (1979). Preliminary studies on the composition and rheological properties of the extracellular polysaccharide synthesized by Pseudomonas PB1 (NCIB 11264). Biochimica et biophysica acta 585, 611-619. 